\title{
White clover roots cause stolon burial
}

\author{
ANN CRESSWELL \\ IGER, Plas Gogerddan, Aberystwyth, Dyfed SY23 3EB, UK
}

Keywords: roots, stolon burial, Trifolium repens L.

\section{Introduction}

A large proportion of clover stolon in the field $(20$ $95 \%$ ) is found below the soil surface (Hay 1983, Sackville Hamilton \& Harper 1989). The proportion increases dramatically through the autumn and is reduced in spring. This pattern of burial has been attributed to earthworm casting and livestock trampling (Hay et al. 1987). In greenhouse experiments we observed that stolons were often held tightly to the soil surface and some nodes on mature stolons were beneath the surface. Three experiments designed to measure downward movement of stolons relative to the soil surface in controlled conditions without trampling or earthworm casting are described.

\section{Materials and methods}

Each stolon in the experiments was grown along a trough of compost. Stolons from the same variety were from different genotypes. A stolon tip from a 'mother' plant of white clover was pegged to the surface of the compost and allowed to grow along the length of the trough. It was severed from the mother plant after three weeks. Auxanometers were used to measure changes in height of the stolon relative to the soil surface.

Experiment 1 . Three stolons of variety Alice were grown in a controlled environment room $\left(16 / 8 \mathrm{hr}, 16 / 10^{\circ} \mathrm{C}\right)$. For each stolon, one auxanometer was attached to a rooted node and a second auxanometer was attached to a metal nut which was placed on the compost surface 2 $\mathrm{cm}$ from the monitored node. Data was collected on a data logger over a three month period.

Experiment 2. Two stolons of Alice and two of AberHerald were grown in the same conditions as experiment 1. This time the auxanometers were attached to two adjacent rooted nodes on each stolon. A hole, approximately $1 \mathrm{~cm}$ deep and $1 \mathrm{~cm}$ in diameter was made in the

\begin{tabular}{clccc}
\hline Experiment & Measurements & & & \\
& & & & \\
1 & Downward movement (mm/day) & -0.044 & Control Point & $\mathrm{P}$ \\
& & -0.028 & 0.021 \\
2 & Downward movement (mm/day) & -0.106 & Node without hole & $\mathrm{P}$ \\
& & Root intact & -0.048 & 0.019 \\
3 & Distance from soil surface to top & -1.475 & 0.125 & 0.017 \\
& of stolon $(\mathrm{mm})$ & & & \\
\hline
\end{tabular}

compost beneath the younger of the two nodes using a jet of water from a wash bottle. Data was recorded for 6 weeks.

Experiment 3. Eight stolons (four each of Alice and AberHerald) were grown in a greenhouse. A hole was made under a rooted node on each stolon in the same way as in experiment 2 . The exposed root was severed in half the stolons, the others were left intact. After 6 weeks of growth a ruler was laid on the compost across the hole and the distance from the ruler to the upper surface of the stolon was measured.

\section{Results and discussion}

The auxanometer data shows that the stolons moved downwards relative to the control points in both experiments. The undermined stolons with intact roots were pulled below the soil surface while those with severed roots were at or above the soil surface. There were no differences between varieties.

The downward movement of the nodes in the first experiment was small but the loam-based compost was packed to a bulk density of 1.16. In the field where the soil surface is soft and wet during the autumn this root effect may play an important role in stolon burial in combination with trampling and wormcasting. Measurement of the force of root contraction and the position of contractile tissues are currently being investigated. Holding the stolon tightly to the soil surface is important as it resists loss of stolon under grazing.

\section{References}

Hay, M.J.M. 1983. Seasonal variation in the distribution of white clover (Trifolium repens L.) stolons among 3 horizontal strata in 2 grazed swards. New Zealand Journal of Agricultural Research 26: 29-34.

Hay, M.J.M.; Chapman, D.F.; Hay R.J.M.; Pennell, C.G.L.; Woods, P.W.; Fletcher, R.H. 1987. Seasonal variation in the vertical distribution of white clover stolons in grazed swards. New Zealand Journal of Agricultural Research 30: 1-8. Sackville Hamilton, N.R.; Harper J.L. 1989. The dynamics of Trifolium repens in a permanent pasture. I. The population dynamics of leaves and nodes per shoot axis. Proceedings of the Royal Society, London B 237: 133-173. 